\title{
MEMAHAMI HUKUM ISLAM DALAM PENAFSIRAN ALQURAN MELALUI QAIDAH BAHASA ARAB
}

\author{
Ahmad Bangun Nasution \\ (Dosen Fakultas Ilmu Tarbiyah dan Keguruan UIN SU) \\ M. Syukri Albani Nasution \\ (Dosen Fakultas Syariah dan Hukum UIN SU)
}

\begin{abstract}
The Qur'an as a guidance for all mankind must be upheld and carried out. The content of the Qur'an has several teachings of life so that a servant will find the happiness in the world and especially in the hereafter. The Qur'an is like an amazing ocean and its uniqueness has never been swallowed up by the times, so the various interpretations emerged with various methods as well. The tafsir books that fulfill the library is a proof of how excited and attentive the scholars in understanding the meanings as well as the messages contained in the Qur'an.
\end{abstract}

Keywords: Qaidah, Al-Qur'an Interpretation, Islamic Law

Abstrak: al-Qur'an sebagai petunjuk bagi seluruh umat manusia, merupakan suatu pedoman yang harus ditegak dan dijalankan. Kandungan isi Al Qur'an memiliki beberapa ajaran kehidupan, agar seorang hamba kelak menemukan kebahagian baik di dunia dan terkhusus di akhirat. Al Qur'an laksana samudra yang keajaiban dan keunikannya tidak akn pernah sirna ditelan masa, sehingga muncullah bermacam-macam tafsir dengan metode yang beraneka ragam pula. Kitab-kitab tafsri yang memenuhi perpustakaan merupakan suatu bukti yang menunjukkan betapa tingginya dan besarnya semangat dan perhatian para ulama dalam menggali serta memahami makna-makna, dan juga pesan-pesan yang terkadung di dalam Al Qur'an

Kata Kunci: Qaidah, Tafsir Al Quran, Hukum Islam

\section{PENDAHULUAN}

Banyak pendekatan dalam Menyikapi perkembangan metodologi dalam pengkajian keislaman, pendekatan Qurani dan Hadis tentu tidak akan pernah luput dari metode dalam penggalian hokum-hukum Islam kontemporer. Oleh karenanya harus banyak pendekatan yang sifatnya Qurani, baik dalam corak penafsiran, metodologi penafsiran Alquran dan semacamnya. Sebab, perkembangan kajian keislaman harus tetap berlandaskan pada nilai-nilai Qurani yang ter-aktual-kan dalam system atau pendekatan dan metodologi pengkajiannya.

Sesunggunya Al-Quran diturunkan format dan uslub yang tidak pernah mereka kenal sebelumnya serta keindahan gaya bahasa yang tak tertandingi oleh para tokoh dan pakar bahasa waktu itu. Kitab suci ini telah menantang para pujangga dan tokohtokoh penyair Arab untuk membuat tandingan bagi Al-Quran, mulai dari terberat/membuat satu saja (Q.S. Yunus: 38), bahkan yang kurang dari 
satu surah (Q.S Al Baqarah: 23). Namun tidak satupun dari tantangan tersebut dapat mereka yakini, malah mereka mengatakan, "sesungguhnya orang ini (Muhammad) benar-benar dalah tukang sihir yang nyata" (Q.S Yunus; 2). Di lain kesempatan mereka mengatakan bahwa Al-Quran hanyalah mitos belaka. Sebagaimana disebutkan dalam surah Al-Furqan: 5 "dan mereka berkata: dongeng-dongeng orang terdahulu, dimintanya supaya dituliskan, maka dibacakanlah kepadanya dongeng itu setiap pagi dan petang".

Pada saat Alquran diturunkan, bangsa Arab bisa mengetahui kemukjizatan Al-Quran melalui fitrah (kemapuan yang dibawa sejak lahir) yang mereka miliki ${ }^{95}$,tanpa melalui penilitian terlebih dahulu. Hal ini dapt dimaklumi karena nalar bahasa mereka pada masa itu tinggi, dan belum banyak berbaur dengan bangsa non-Arab. Diantara bukti konkrit yang dicatat sejarah adalah pernyataan Al-Muhgirah (salah seorang tokoh Quraisy), yang sangat takjub setelah mendengar keindahan bahasa Al Qur'an. Bahkan diantara mereka (musyrikin Quraisy) ada yang langsung sujud setelah mendengar bacaan ayat: "Fashda' bima tukmar wa 'a'ridh 'anil musyrikin". Ketika ditanya, "apakah kamu telah masuk Islam? Orang tersebut menjawab: "tidak, tapi saya telah mendengar perkataan yang sangat menabjubkan". ${ }^{96}$

Perkembangan sejarah Al Qur'an

95 Lihat, Al-I'jaz Al-Qur'ani, (Kumpulan Makalah Simpoium tentang I'jaz Al-Qur'an di Baghdad, 1990), hal. 462

96 Ali Al'amari, Haula I'jaz Al-Quran Suplemen Majalah Al-Azhar, 1419, hal. 4 telah mengalami kemajuan pesat, baik pada keberadaan dan eksisitensi $\mathrm{Al}$ Qur'an itu sendiri, maupun kajiankajian yang berhubungan dengannya. Lebih dari seratus cabang ilmu pengetahuan yang bersumber dari $\mathrm{Al}$ Qur'an, dan salah satunya adalah tafsir Al Qur'an al Karim.

Fungsi dan kedudukan ilmu tafsir sangat tinggi dalam kajian-kajian ulum Al Qur'an. Kalam Allah ini sarat mengandung hukum, norma-norma dan ilmu pengetahuan yang banyak, maka kegunaan tafsir ini diantaranya adalah untuk memahami dan mengetahui maksud Allah mengenai syariat-Nya, akidah dan petunjuk-petunjuk lainnya.

Dalam makalah sederhana ini, akan dikemukakan isnya Allah, salah satu metode penafsiran yang sering kita dengar, yakni metode penafsiran ijmali dan metode penafsiran tahlili, serta selanjutnya akan dibahas bagaimana penafsiran dengan metode ini serta kelebihan dan kekurangan kedua metode ini.

\section{PENGERTIAN \\ METODE \\ PENAFSIRAN AL QUR'AN}

Kata metode dalam kamus besar bahasa Indonesia diadopsi dari kata methodos dalam bahasa Yunani. Kata tersebut terdiri dari dua kata yakni metha, yang berarti menuju, melalui, mengikuti, dan kata hodos yang berarti jalan, perjalanan, cara, arah. Kata methodos sendiri berarti penelitian, metode ilmiah, hipotesa ilmiah, uraian ilmiah. ${ }^{97}$ Dalam bahasa Inggris, kata tersebut ditulis dengan method dan dalam bahasa Arab diterjemahkan

97 Anton Baker, Metode-metode Filsafat, Ghalia Indonesia, Jakarta, cet. 1, 1984, hal. 10 .

147 | Memahami Hukum Islam Dalam Penafsiran Alquran Melalui Qaidah Bahasa Arab 
dengan manhaj atau thariqah. Dalam bahasa Indonesia kata tersebut mengandung arti cara yang teratur terpikir baik-baik untuk mencapai maksud (dalam ilmu pengetahuan dan juga lainnya), cara kerja yang bersistem untuk memudahkan pelaksanaan suatu kegiatan untuk mencapai sesuatu yang ditentukan. ${ }^{98}$

Dalam hal ini, metode merupakan salah satu sarana terpenting untuk mencapai tujuan yang telah ditetapkan. Dengan demikian, studi tafsir Al Qur'an tidak terlepas dari metode penafsiran, yakni cara sistematis untuk mencapai pemahaman yang benar tentang maksud Allah di dalam Al Qur'an, baik yang didasarkan pada pemakaian sumbersumber penafsirannya, sistem penjelasan tafsiran-tafsirannya, keluasan kejelasan tafsiranny maupun yang didasarkan pada sasaran dan sistematika ayat yang ditafsirkannya.

Pernyataan sekaligus definisi diatas, secara implisit, memberikan indikasi bahwa metode mengandung seperangkat kaedah dan aturan yang harus diperhatikan oleh mufassir agar terhindar dari kesalahan dan penyimpangan dalam menafsirkan $\mathrm{Al}$ Qur'an.99

Ada baiknya sebelum memulai pembahasan tafsir ijmali dan tahlili, penulis terlebih dahulu mengemukakan pengertian tafsir, dan definisi ijmali serta tahlili.

Secara etimologi tafsir adalah menjelaskan dan menerangkan serta

98 Tim Penyusun, Kamus Besar Bahasa Indonesia, Balai Pustaka, (Jakarta, Cet. Ke-1, 1988), hal. 580-581.

99 Supiana dan M. Karman, Ulumul Qur'an dan Pengenalan Metodologi Tafsir, Pustaka Islamika, (Bandung, Cet ke-1, 2002), hal. 302. menyatakan. Dan menurut istilah banyak pendapat ulama dalam mendefinisikannya diantaranya adalah;

1. Al Kilbiy dalam at Tashiel menyatakan:

$$
\begin{aligned}
& \text { التفسير: شحح القرآن وبيان معناه ولإفضاح بما } \\
& \text { يقتضيه بنصه او اشارته او نجواه. } 100
\end{aligned}
$$

Tafsir ialah: Mensyarahkan Al Qur'an, menerangkan maknanya dan menjelaskan apa yang dikehendakinya dengan nashnya atau dengan isyaratnya, atau dengan najuannya.

2. Zarkasiy dalam al Burhan mendefinisikan tafsir dengan

التفسير: بيان معاني القرآن واستخراج احكامه و<smiles>[Mg][AsH2]</smiles>

Tafsir adalah menerangkan makna-makna Al Qur'an dan mengeluarkan hukum-hukumnya dan hikmah-hikmahnya.

3. al Jurjaniy berkata:

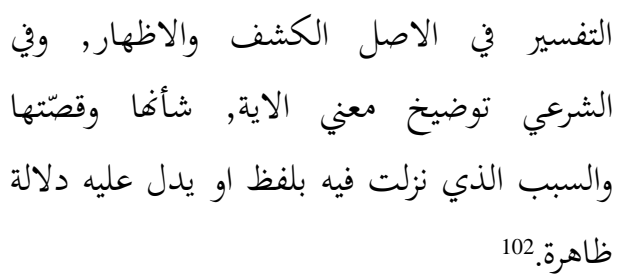

Tafsir pada asalnya adalah membukan dan menzahirkan. Pada istilah syara' ialah menjelaskan makna ayat, urusannya, kisahnya dan sebeb yang karenanya diturunkan ayat, dengan lafaz yang menunjuk kepadanya secara jelas.

100 M. Hasybiy as Shiddiqiy, Sejarah dan Pengantar Ilmu Al Qur'an dan Tafsir, (Jakarta: Bulan Bintang, Cet ke empar belas, 1992), hal. 178.

101 Ibid, hal. 178.

102 Ibid, hal. 179. 


\section{SEPUTAR TAFSIR IJMALIY}

Kata Ijmaliy secara bahasa adalah global. Dengan demikian tafsir ijmaliy adalah metode tafsir yang menafsirkan ayat-ayat $\mathrm{Al}$ Qur'an dengan cara mengemukakan maknanya secara global. ${ }^{103}$

Al Tafsir al Ijmaliy ini menempuh cara penafsiran ayat-ayat Al Qur'an berdasarkan susunan ayat-ayat yang ada di dalam mushaf Usmaniy. Seorang mufassir memaparkan ayat demi ayat, surat demi surat secara teratur dengan penjelasan sederhana sehingga memungkinkan seorang pembaca dapat memahaminya, baik pembaca tersebut orang-orang yang istimewa, seperti tinggi ilmu pengetahuannya atau orang lain yang awam. Tujuan asasi penafsiran dengan metode ini adalah menggunakan bahasa yang dipergunakan oleh jumhur untuk mendekatkan makna supaya dapat dipahami pembaca. Dalam menafsirkan ayat-ayat $\mathrm{Al}$ Qur'an mufassir menggunakan hadist Nabi, atsar salaf shalih, kejadian sejarah, kisah-kisah yang termaktub di dalam Al Qur'an dan juga menyebutkan sebab-sebab diturunkan ayat jika ada. 104

Seorang mufassir di dalam tafsirnya menggunakan kata dari bahasa Arab yang mirip bahkan tekadang sama dengan lafaz $\mathrm{Al}$ Qur'an, sehingga pembaca akan merasakan bahwa uraiannya tersebut tidak jauh dari lafaz-lafaznya.

Satu sisi karya ini dinilai betul-betul sebagai karya tafsir, dan pada sisi lainnya

103 Abd al Hayy al Farmawiy, Al Bidayah Fi al Tafsir al Maudhuiy; Dirasah Manhajiyah al Mauwdhu'iy, Metode Tafsir Maudhui, Terj Suryan A. Jamrah (Jakarta: Raja Grafindo Persada, 1996), hal. 29

${ }_{104}$ Zahir bin 'Iwadh al Ma'iy, Dirasat fi at Tafsir al Maudhu’i lil Qur'an al Karim, hal. 17. benar-benar memiliki hubungan erat dengan susunan bahasa Al Qur'an. cara penafsiran dengan uslub yang demikian, akan dapat memudahkan seorang pembaca untuk memahaminya.

Diantara beberapa kitab tafsir yang ditulis dengan sesuai metode ini adalah;

1. Tafsir Al Qur'an al Karim oleh Muhammad Farid Wajdi.

2. Tafsir Al Qur'an ak Karim, oleh Jalaluddin as Suyuthi dan Jalaluddin al Mahalliy.

3. Tafsir al Wafiz fi Tafsir Al Qur'an al Karim, oleh Syauq Dhaif.

4. Tafsir al Wadih oleh Muhammad Mahmud Hijazi

5. Tafsir Al Qur'an al Karim, oleh Mahmud Muhammad Hadan 'Ulwan dan Muhammad Ahmad Barmiq. ${ }^{105}$

\section{SEPUTAR TAFSIR TAHLILIY}

Tafsir Tahlili (analitis) atau yang juga disebut dengan tafsir tajzi i merupakan suatu metode yang bermaksud menjelaskan dan menguraikan kandungan ayat-ayat $\mathrm{Al}$ Qur'an dari seluruh sisinya, sesuai dengan urutan ayat di dalam suatu surat. Dalam tafsir ini ayat ditafsirkan secara komprehensif dan menyeluruh baik dengan corak ma'tsur maupun ra'yi. Unsur-unsur yang dipertimbangkan adalah asbabun nuzul, munasabah ayat dan juga makna harfiyah setiap kata. ${ }^{106}$

Seorang mufassir tersebut bermaksud menjelaskan ayat-ayat $\mathrm{Al}$ Qur'an secara terperinci dan jelas. Metode tafsir ini dilakukan sesuai dengan susunan ayat demi ayat atau surat demi surat sebagaimana

105 Ibid, h. 18, lihat juga: H Muhammad Amin Suma, Studi Ilmu-ilmu Al Qur'an 2, (Jakarta: Pustaka Firdaus, 2001), hal. 113

106 Azyumardi Azra, Sejarah Ulumul Qur'an, (Jakarta: Pustaka Firdaus), hal. 172174.

149 | Memahami Hukum Islam Dalam Penafsiran Alquran Melalui Qaidah Bahasa Arab 
termaktub dalam mushaf Usmaniy. Tujuan utama metode tafsir ini adalah untuk mengungkapkan maksudmaksud dari ayat tersebut dan tunjukannya. Seorang mufassir akan memaparkan lafaz dari segi bahasa Arab, penggunaannya, kesesuaian ayat dengan ayat serta tempat dan juga sebab turunnya ayat tersebut jika memang ada. Mufassir akan menguraikan fasahah, bayan, i’jaz dan maksud syariat dibelakang nas dan sebagainya. dalam menafsirkan ayat demi ayat, seorang mufassir sering mengutip ayat Al Qur'an, hadist Rasulullah SAW, serta perkataan sahabat dan para tabiin. ${ }^{107}$

Beberapa kitab tafsir yang menggunakan metode ini diantaranya adalah;

1. Tafsir Jami al Bayan fi Tafsir Al Qur'an al Karim oleh Abu Ja'far Muhammad bin Jarir at Thabariy.

2. Tafsir Al Qur'an al Azhim oleh Ibnu Katsir.

3. Tafsir Mafatih al Ghaib oleh Fakhru Raziy.

4. Tafsir al Jami' li Ahkam Al Qur'an oleh Qurthubiy. ${ }^{108}$

\section{KEISTIMEWAAN KELEMAHAN}

DAN

Dalam menganalisa tafsri ijmali dan tahlili, muncul beberapa pertanyaan yang berkenaan dengan kegunaan kedua metode penafasiran ini, diantaranya adalah apa keistimewaan dan kelemahan metode tafsir ini, dan bagaimana pula contohnya.

Dalam bagian ini akan dibahas insya Allah mengenai keistimewaan dan juga kelemahan kedua tafsir ini.

\footnotetext{
${ }^{107}$ Ibid, hal 18

108 Ibid,
}

Suatu metode yang dilahirkan seorang manusia, selalu saja memliki kelemahan dan keistimewaan. Demikian halnya juga dengan metode ijmali ini. Namun perlu disadari keistimewaan dan kelemahan yang dimaksud disini bukanlah suatu hal yang negatif, akan tetapi rujukan dalam ciri-ciri metode ini.

Metode ijmali, sebagai salah satu metode penafsiran Al Qur'an memiliki beberaa keistimewaan yang tidak dimiliki oleh tafsir-tafsir lainnya, diantara keistinmewaan ini adalah;

a Praktis dan Mudah di pahami.

Sesuai dengan sebutannya, tafsir ijmali ini merupakan penafsiran yang dalam menafsirkan suatu ayat tidak terbelit-belit, ringkas dan mudah dipahami oleh pembacanya. Selain itu juga pesanpesan yang terkandung dalam tafsir ini, sangat mudah ditangkap oleh pembaca.

b Bebas dari penafsiran Israiliyat

Peluang masuknya penafsiran Israiliyat dalam metode penafsiran ini dapat dihindarkan, bahkan dapat dikatakan sangat jarang sekali ditemukan. Hal ini disebabkan uraiannya yang singkat hanya mengemukakan tafsir dari kata-kata dalam suatu ayat dengan ringkas dan padat.

c Akrab dengan bahasa Al Qur'an Uraiannya yang singkat dan padat mengakibatkan tidak dijumpainya penafsiran ayat-ayat Al Qur'an yang keluar dari kosa kata ayat tersebut. Metode ini lebih mengedepankan makna sinonim dari kata-kata yang bersangkutan, sehingga bagi pembacanya merasa dirinya sedang membaca $\mathrm{Al}$ Qur'an dan bukan membaca suatu tafsir.

Adapun kelemahan yang dimiliki metode penafsiran ini 
diantaranya adalah;

a Menjadikan petunjuk Al Qur'an bersifat parsial.

Penafsiran yang ringkas dan pendek membuat pesan Al Qur'an tersebut tidak utuh dan terpecahpecah. Menurut Subhi Saleh kandungan ayat-ayat Al Qur'an mempunyai keistimewaan dalam hal kecermatan dan cakupannya yang menyeluruh. Setiap kita menemukan ayat yang bersifat umum yang memerlukan makna lebih lanjut, kita pasti menemukan pada bagian lain, baik yang bersifat membatasi maupun memperjelas secara rinci. 109

b Terlalu dangkal dan berwawasan sempit

Tafsir ini tidak menyediakan ruangan untuk memberikan uraian atau pembahasan yang memuaskan beekenaan dengan pemahaman suatu ayat. Ini boleh disebut suatu kelemahan yang harus disadari para mufassir yang akan menggunakan metode ijmali ini.

Pada sisi selanjutnya, akan dibahas tentang keistimewaan dan kelemahan yang terdapat dalam metode penafsiran tahlili, berikut pemaparannya.

Dalam tafsir tahlili ditemukan beberapa keistimewaan diantaranya adalah tafsir ini biasanya selalu memaparkan beberapa hadist ataupun perkataan sahabat dan para tabiin, yang berkenaan dengan pokok pembahasan pada ayat. Juga didalamnya terdapat beberapa analisa mufassir mengenai hal-hal umum yang terjadi sesuai dengan ayat. Dengan

${ }^{109}$ Subhi Salih, Mabahis Fi Ulumil Qur'an, trjmh Tim Pustaka Firdaus, cet kedelapan, (Jakarta: Pustaka Firdaus), hal 299. demikian, informasi wawasan yang diberikan dalam tafsir ini sangat banyak dan dalam.

Disamping keistimewaan, juga ada kelemahan. Namun sekali lagi kelemahan disini bukanlah merupakan kelemahan yang mengharuskan kita tidak menggunakan atau mengabaikan tafsir ini. Akan tetapi hendaknya dalam menyikapi kelemahan ini, kita haru dapat memilah milih beberapa informasi dan wawasan yang dipaparkan dalam metode penafsiran ini. Seperti halnya penafsiran Israiliyat, mungkin terkadang masuk dalam informasi yang diberikan mufassir. Juga sama halnya dengan berbagai hadist lemah yang tidak selayaknya digunakan pada tempat dan kondisi sesuai.

\section{CONTOH DAN HUBUNGANNYA}

Contoh dalam penafsiran Ijmaliy ini dapat kita lihat pada tafsir al Jalalain, yang hanya membutuhkan beberapa baris saja saat menafsirkan lima ayat pertama di dalam surat al Baqarah. Al Jalalain saat menafsirkan Firman Allah QS al Baqarah 1 memaparkan "لالم" misalnya dia berkata Allah Yang Maha Tahu maksudnya. Demikian pula halnya saat menafsirkan Firman Allah "الكتاب" hanya menyatakan yang dibaca oleh Muhammad SAW. "berfungsi sebagai predikat dan subjeknya adalah

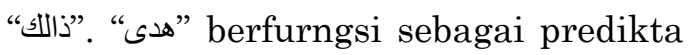
kedua bagi "ذاك" yang mengandung arti memberi petunjuk bagi orang yang bertaqwa. ${ }^{110}$

Berbeda halnya dengan imam

110 Jalaluddin al Mahalli dan Jalaluddin as Suyuthiy, Tafsir Al Qur'an al 'Azhim, juz 1, (Semarang: Toha Putra), hal. 2 
Qarthubiy dalam tafsirnya al Jami' Liahkamil Qur'an, yang membutuhkan tiga halama dalam menjelaskan atau menafsirkan Firman Allah QS Al Baqarah 1. Imam memulai penafsiran ayat ini dengan mengemukakan pentakwilan huruf-huruf muqattha'ah di dalam Al Qur'an. didalamnya ada beberapa pendapat diantaranya yang dikemukakan 'Amir as Sya'biy dan Sufyan at Tsauriy beserta sekelompok muhaddistin yang menyatakan hurufhuruf muqattha'ah adalah bentuk rahasia-rahasia Allah, yang hanya Allah Mengetahuinya dan kita tidak perlu untuk membahas dan membicarakannya. Dalam pendapat ini Qurthubiy memaparkan beberapa perkataan sahabat yang berkenaan dengan masalah ini, diantaranya perkataan Abu Laist ats Tsamarqadiy dari Umar, Ustman dan Ibnu Mas'ud yang berkata: "Huruf-huruf muqattha'ah tidak perlu untuk ditafsirkan.

Kemudian pada pendapat lainnya, imam memaparkan pendapat yang mengharuskan orang mukmin untuk membahas dan membicarakan tentang huruf-huruf muqattha'ah, untuk mengambil faedah-faedah yang tersirat di dalamnya. Dalam pendapat ini terdapat berbagai perbedaan pendapat lain diantaranya menyatakan bahwa huruf-huruf muqattha'ah merupakan Asma Allah. Pendapat lainnya menyatakan huruf-huruf muqattha'ah ini adalah isyarat dari huruf hijaiyah yang hanya Allah mengetahui maksud yang tersirat di dalamnya. Pendapat selanjutnya adalah pendapat sekelompok ulama yang menyatakan bahwa huruf-huruf muqattha'ah ini adalah diambil dari
Asma Allah yang sebagian dari katakatanya dihapus. Misalnya huruf alif diambil dari kata Allah, huruf laam diambil dari kata Jibril, dan huruf miim diambil dari kata Muhammad. Dan juga ada yang berpendapat lain bahwa huruf-huruf muqattha'ah ini diambil dari dari Asma Allah kesemuanya. Huruf aliif dari Allah, huruf laam dari Asma Allah Latif, dan huruf miim diambil dari Asma Allah Majiid. ${ }^{111}$

Kemudian pada selanjutnya imam memaparkan pendapat lain mengenai huruf-huruf muqattha'ah ini yaitu yang dikemukakan oleh Zaid bin Aslam yang menyatakan bahwa hurufhuruf muqattha'ah ini adalah namanama surat di dalam Al Qur'an. selanjutnya al Kalbiy mengatakan bahwa huruf-huruf muqattha'ah ini adalah bentuk sumpah Allah. Juga dalam pendapat-pendapat diatas imam Qurthubiy juga memaparkan beberapa perbedaan dan perdebatan ulama dalam ikhtilaf ini. ${ }^{112}$

Kemudian imam membahas kata dzalika dan kata kitab. Dalam masalah ini imam memaparkan penafsirkan dzalika dengaan isyarat kepada $\mathrm{Al}$ Qur'an, yang dilakukan oleh Abu Ubaidah dan Akramah. Contohnya adalah Firman Allah lainnya

$$
\text { تلك ايات الله نتلوها عليك بالحق }
$$

Megenai kata Kitab, terdapat beberapa pendapat dalam penafsirannya, diantaranya;

Dzalika kitab yakni kitab yang telah Aku

111 Muhammad bin Ahmad al Anshariy al Qurthubiy, al Jami' Liahkamil Qur'an, Darul Ulumil Qur'an, juz 1, hal. 128.

112 Ibid, hal. 129-130. 
tulis atas makhluk-makhluk, dengan berbagai bentuk kesedihan, kegembiraan, ajal rezeki yang tidak ada keraguan di dalamnya. Ada juga yang berpendapat dzalikal kitabu adalah suatu isyarat kepada Lauhul Mahfuz. Yang lainnya berpendapat dzalikal kitabu adalah Kitab yang dijanjikan Allah kepada Nabi-Nya yang tidak akan terhapus oleh air. Juga ada yang berpendapat maksudnya adalah isyarat kepada apa yang termaktub di dalam Taurat dan Injil, serta juga ada yang berpendapat kata tersebut maksudnya adalah suatu isyarat akan apa yang telah diturunkan Allah di Makkah atau yang lazim disebut surat-surat Makkiy. Serta beragam pendapat lainnya yang tidak dapat ditulis penulis kesemuanya.

Dalam penafsirkan "نيه هدي للمتقبين" juga terdapat beberapa permasalahan, dan pada makalah ini penulis akan memaparkan sebagian dari kesemuanya.

Pertama, hudaan adalah petunjuk yang didapat oleh para Rasul beserta para pengikut mereka. Kedua, ada yang menafsirkan hudaa disini adalah salah satu nama sungai, karena sungai merupakan suatu tempat yang sangat dibutuhkan manusia dalam kehidupan sehari-harinya, sebagaimana juga hidayah/petunjuk sangat dibutuhkan manusia untuk menemukan kebahagian hidup.

Kemudian imam memaparkan makna taqwa menurut beberapa ulama, diantaranya ada yang menafsirkan taqwa adalah kebaikan, juga ada yang menafsirkan taqwa disini dengan sedikit cakap. Karena kata taqwa asalnya adalah sedikit cakap. Serta berbagai permasalahan lainnya yang diutarakan imam Qurthubiy dalam menafsirkan ayat pertama surat al Baqarah ini. 113

Dari pemaparan contoh dari kedua bentuk penafsiran ini, dapat dilihat perbedaan mendasar dalam

${ }^{113}$ Ibid, hal. 130-131 penafsiran ayat Al Qur'an dengan menggunakan kedua metode ini. Yang mana tafsir ijmali menafirkannya dengan metode ringkas dengan bahasa yang populer, mudah dimengerti, yang polanya adalah meletakkan tafsir di dalam rangkaian ayat-ayat seperti penjelasan kata yang kemudian disimpulkan dengan penjelasan yang umum.

Sedangkan tafsir tahliliy menggunakanpenafsiran secara komprehensif dan menyeluruh dengan mengunakan corak ma'tsur maupun ra'yi, dan keduanya sama-sama menafsirkan ayat dengan sesuai urutan ayat di dalam suatu surah.

\section{PENUTUP}

Corak penafisran Al Qur'an yang dilakukan sejak zaman Rasulullah SAW sudah banyak mengalami perkembangan, khususnya dalam bidang metodologi. Pada awalnya, penafasiran Al Qur'an dilakukan dengan metode riwayat, atau yang kerap dikenal dengan Tafsir bil Ma'tsur. Selanjutnya metode ini mengalami perkembangan, hingga metode yang menggunakan logika, atau yang kerap dikenal dengan tafsir bil Ra'yi. Metode ini menggunakan logika dalam menafsirkan ayat, disamping juga menggunakan riwayat yang ada.

Perkembangan selanjutnya, adalah metode penafsiran penalaran, dimana kitab-kitab tafsir diklasifikasikan kepada salah satu metode penafsiran baik ijmaliy, tahlili, muqarin, maupun maudhu'i.

Metode tafsir ijmali dan Tahlili merupakan salah satu metode penafsiran yang berusaha untuk mengungkapkan kandungan makna yang tersirat di di dalam Al Qur'an. dengan berbagai keistimewaan dan keterbatasannya, kedua metode ini dapat membantu orang baik itu awam maupun intelektual untuk menggali makna yang tersirat. Namun terlepas 
dari keistimewaan dan

keterbatasannya, kedua metode tafsir ini telah menjadi khazanah bagi umat Islam, terkhusus ahli tafsir dalam usaha menafsirkan ayat-ayat $\mathrm{Al}$ Qur'an.

Metode penafsiran diatas, pada dasarnya adalah usaha untuk menjelaskan ayat serta hikmat yang tersirat di dalam suatu ayat Al Qur'an. perbedaan bentuk yang banyak, adalah sebagai bentuk kekayaan khazanah dalam bidang tafsir ini. Kesemuanya memiliki kesempurnaan dan keterbatasan, sehingga kesemuanya dapat saling membantu dan juga menutupi satu dengan lainnya. 


\section{DAFTAR PUSTAKA}

Abd al Hayy al Farmawiy, Al Bidayah Fi al Tafsir al Maudhuiy; Dirasah Manhajiyah al Mauwdhu'iy, Metode Tafsir Maudhui, Terj Suryan A. Jamrah (Jakarta: Raja Grafindo Persada, 1996)

Ali Al'amari, Haula I’jaz Al-Quran Suplemen Majalah Al-Azhar

Al-I'jaz Al-Qur'ani, (Kumpulan Makalah Simposium tentang I'jaz Al-Qur'an di Baghdad, 1990)

Anton Baker, Metode-metode Filsafat, Ghalia Indonesia, Jakarta, cet. 1, 1984

Azyumardi Azra, Sejarah Ulumul Qur’an, Pustaka Firdaus, Jakarta, 1999.

H Muhammad Amin Suma, Studi Ilmu-ilmu Al Qur'an 2, Pustaka Firdaus, Jakarta, 2001

M. Hasybiy as Shiddiqiy, Sejarah dan Pengantar Ilmu Al Qur'an dan Tafsir, Bulan Bintang, Jakarta, Indonesia, Cet ke empar belas, 1992

Muhammad bin Ahmad al Anshariy al Qurthubiy, al Jami' Liahkamil Qur'an, Darul Ulumil Qur'an, Kairo, juz 1

Subhi Salih, Mabahis Fi Ulumil Qur'an, trjmh Tim Pustaka Firdaus, cet kedelapan, Jakarta, Pustaka Firdaus

Supiana dan M. Karman, Ulumul Qur'an dan Pengenalan Metodologi Tafsir, Pustaka Islamika, Bandung, Cet ke-1, 2002

Tim Penyusun, Kamus Besar Bahasa Indonesia, Balai Pustaka, Jakarta, Cet. Ke-1, 1988

Zahir bin 'Iwadh al Ma'iy, Dirasat fi at Tafsir al Maudhu’i lil Qur'an al Karim 